\title{
Effects of pioneering plants on microbial structures and functions in a glacier forefield
}

\section{Journal Article}

\section{Author(s):}

Miniaci, Ciro; Bunge, Michael; Duc, Laurence; Edwards, Ivan; Bürgmann, Helmut; Zeyer, Josef

Publication date:

2007

Permanent link:

https://doi.org/10.3929/ethz-b-000005783

Rights / license:

In Copyright - Non-Commercial Use Permitted

Originally published in:

Biology and Fertility of Soils 44(2), https://doi.org/10.1007/s00374-007-0203-0 


\title{
Effects of pioneering plants on microbial structures and functions in a glacier forefield
}

\author{
Ciro Miniaci • Michael Bunge - Laurence Duc • \\ Ivan Edwards · Helmut Bürgmann • Josef Zeyer
}

Received: 5 July 2006/Revised: 4 April 2007 / Accepted: 4 April 2007 / Published online: 9 May 2007

(C) Springer-Verlag 2007

\begin{abstract}
This study investigates the small-scale spatial impact of the pioneering plant Leucanthemopsis alpina (L.) Heywood (L. alpina) on biological and chemical-physical parameters in an early successional stage of a glacier forefield. Considering the frequent occurrence of isolated patches of this pioneer plant in the forefield of the Dammaglacier (Switzerland), we hypothesized that the impact of the plant would establish gradients in nutrients, and microbial community structure and activity that may be of importance for the successional processes occurring in the forefield. Our results indicated that, in young successional soils, the rhizosphere effect of L. alpina plant patches can influence bacterial cell numbers and activities not only within the root zone, but even at $20 \mathrm{~cm}$ distance from the plant. Microbial cell counts, active cells, and saccharase, glucosidase, and acid phosphatase activities revealed
\end{abstract}

C. Miniaci $(\bowtie) \cdot$ L. Duc $\cdot$ J. Zeyer

Department of Environmental Sciences,

Swiss Federal Institute of Technology (ETH Zurich),

Universitätstrasse 16,

CH-8092 Zurich, Switzerland

e-mail: miniaci@env.ethz.ch

M. Bunge

Institute of Microbiology,

University of Innsbruck,

A-6020 Innsbruck, Austria

Present address:

I. Edwards

School of Natural Resources and Environment,

Ann Arbor, MI 48109-1041, USA

Present address:

H. Bürgmann

Centre of Ecology, Evolution and Biogeochemistry,

Swiss Federal Institute of Aquatic Science and Technology,

Eawag,

6047 Kastanienbaum, Switzerland significant distance effects, decreasing from soil directly underneath the plant to soils at 20 and $40 \mathrm{~cm}$ distance. Soil chemical and physical parameters did not exhibit significant trends. Fingerprinting analysis of amplified 16S rDNA fragments was used to characterize the microbial community. A selective effect of the plant on the microbial community could not be shown because the bacterial communities were similar regardless of distance to the plant.

Keywords Glacier forefield · Pioneering plants .

Plant-bacteria interaction - Soil bacteria - Soil development . Enzyme activity $\cdot$ Active biomass

\section{Introduction}

The majority of Swiss glaciers are currently receding as a consequence of global warming (Haeberli and Beniston 1998). Since 1850, around the end of the little Ice Age, European glaciers lost about $50 \%$ of their original glaciated area (Zemp et al. 2006). The forefield of receding glaciers is initially vegetation-free, with low nutrient content (Sigler et al. 2002; Darmody et al. 2005). In a continuous glacier retreat, greater distance from the termini corresponds to longer periods of ice-free exposure, resulting in a successional chronosequence (Matthews 1992).

Whereas the succession of flora and fauna has been extensively studied in this system (Matthews 1992; Chapin et al. 1994; Kaufmann 2001; Caccianiga and Andreis 2004; Hodkinson et al. 2004), few studies addressed bacterial processes in glacier forefields (Ohtonen et al. 1999; Sigler and Zeyer 2002; Bardgett and Walker 2004; Tscherko et al. 2004). Sigler and Zeyer (2002), using molecular methods, reported that community structures and metabolic functions change along the chronosequence of a glacier forefield. Tscherko et al. (2003) demonstrated that microbial functional diversity increased along a glacier forefield chronosequence. 
As plant-cover is one of the most obvious gradients in a glacier forefield, microbial activity is likely to vary with vegetation. Plants translocate between 5 and $60 \%$ of their photosynthetically fixed carbon into the rhizosphere, which may stimulate microbial communities and their associated enzymatic activities (Marschner 1995; Walker et al. 2003). However, along a glacier forefield chronosequence, the interaction between microorganisms and vegetation might differ at the various successional stages. Tscherko et al. (2004) investigated microbial community structure and enzymatic activities in the rhizosphere and bulk soil of Poa alpina plants at various successional stages of a glacier forefield. In an additional study, Tscherko et al. (2005) investigated the interrelationship of different successional plant communities with microbial diversity and enzymatic activity patterns, providing evidence that microbial community structure and enzymatic activity patterns are strongly conditioned by the successional stage, as well as the carbon and nitrogen content of the forefield soils. The relationship between chronosequence and microbial community structure in bulk and rhizospheric soils of the pioneering plant $L$. alpina was investigated by Edwards et al. (2006). A major focus of this study was the changing patterns of rhizodeposits (in the form of organic acids and sugars) in the L. alpina rhizosphere and how they can condition the structure of microbial communities, as well as their ecological strategies.

Patchy vegetation is a common observation in early successional stages. A question not addressed by the previous literature is the spatial extent of plant microbial interaction in these environments. We hypothesized that pioneer plants provide hot spots of microbial activity that extend into the surrounding bulk soil, leading to gradients in soil chemistry, microbial activity, and microbial community structure. To address this question we chose L. alpina because it is one of the earliest and most abundant vascular plant pioneers in the young Dammaglacier forefield soils and because there are previous studies on the plantmicrobial interactions for this plant (Edwards et al. 2006). The current work therefore focuses on resolving the spatial effect of L. alpina on microbial cell counts, community structure, and enzyme activities in an early successional soil. We applied chemical-physical measurements (e.g., $\mathrm{pH}$, dissolved carbon, and nitrogen parameters) to describe the conditions for the microbial community. Microbiological (microscopic counts of total and active cells) and molecular [fingerprinting of bacterial 16S rDNA genes using restriction fragment length polymorphisms (RFLP) and denaturing gradient gel electrophoresis (DGGE)] methods describe the size and structure of the microbial community, respectively, and enzymatic activity assays (saccharase, glucosidase, phosphatase, and urease) were selected to reflect major microbial processes related to nutrient cycling and energy metabolism. In combination, these data provide detailed information about chemical and biological gradients around isolated patches of $L$. alpina plants.

\section{Materials and methods}

Field site and sample collection

The research site at the terminus of the Dammaglacier is located in the Central Alps, in the canton of Uri, Switzerland ( $\mathrm{N} 46^{\circ} 38.177^{\prime}$ E $008^{\circ} 27.677^{\prime}$ ), about $2,100 \mathrm{~m}$ above sea level. The climate in this area is characterized by a short vegetation period, and about 2,400 $\mathrm{mm}$ precipitation per year (Sigler and Zeyer 2002). Between July and October 2003, we noted very large day-night temperature fluctuations, the observed maximum and minimum soil surface temperatures ranged between 38 and $0^{\circ} \mathrm{C}$. At the research plot, soil conditions varied between fine fluvial sands and coarse sandy areas.

Sampling took place shortly after snow melt in May 2003. Plants were collected from three isolated patches of L. alpina that were situated about $60 \mathrm{~m}$ distant from the glacier terminus, corresponding to a deglaciation time of 5 to 10 years. L. alpina occurred at a frequency of about 1,000 individuals per hectare at this location. The whole plants including roots were collected for determination of root biomass. The soil attached to the roots together with soil from within $10 \mathrm{~cm}$ of the plants was collected and arbitrarily considered as plant center soil. In addition, samples were taken along two transects from two further distance classes, at $20 \mathrm{~cm}$ and at $40 \mathrm{~cm}$ distance from the $L$. alpina plants. For each distance class, up to four samples were collected from the $0-5 \mathrm{~cm}$ soil layer; larger rocks prevented sampling in some cases. The samples were sieved $(2 \mathrm{~mm})$ and homogenized, and roots were manually separated from soil samples. Subsamples were dried at $105^{\circ} \mathrm{C}$ for $24 \mathrm{~h}$ and subsequently weighed for dry mass determination of root material and soil.

\section{Analysis}

Soil chemical properties were analyzed by extracting field moist soil samples with $0.01 \mathrm{M} \mathrm{CaCl}_{2}$ (ratio 1:5 of soil/ extractant). Samples were shaken for $1 \mathrm{~h}$ in an overhead shaker. Nitrate, phosphate, total sugars, and organic acids were determined in $\mathrm{CaCl}_{2}$ extracts. Ion chromatography with suppressed conductivity detection (DX-100, Dionex, Sunnyvale, CA, USA) was used to measure nitrate, phosphate, lactate, acetate, propionate, formate, butyrate, pyruvate, oxalate, and citrate in their anionic forms (Edwards et al. 2006). Total soluble sugars were determined by acid hydrolysis as glucose equivalents (Chabrerie et al. 2003). Available $\mathrm{NH}_{4}^{+}$was measured colorimetrically by 
extracting soil samples with $2 \mathrm{M} \mathrm{KCl}$ (ratio 1:5 of soil/ extractant) shaken for $1 \mathrm{~h}$ at room temperature (Mulvaney 1996). Soil pH was measured (MP 225, Mettler-Toledo, Greifensee, Switzerland) by diluting $5 \mathrm{~g}$ of air-dried soil in $15 \mathrm{ml} 0.01 \mathrm{M} \mathrm{CaCl}_{2}$ solution. Total organic C (TOC) and total $\mathrm{N}$ were determined by combustion of finely ground air-dried soil samples using a LECO 932 CHNS device (Leco, Krefeld, Germany).

Bacterial cells were fixed in field moist soil samples (1 g) with 4\% paraformaldehyde in phosphate-buffered saline solution $(\mathrm{pH} 7)$. Total bacterial cell numbers were determined after 4'6-diamidino-2-phenylindole (DAPI) staining using an epifluorescence microscope (Zarda et al. 1997). Active bacterial cells were counted after fluorescein diacetate (FDA) hydrolysis by bacterial cells based on the method cited by Alef (1995) with minor changes. Briefly, field moist soil samples $(5 \mathrm{~g})$ were diluted in $5 \mathrm{ml}$ of $60 \mathrm{mM}$ phosphate buffer ( $\mathrm{pH}$ 7.6) and shaken with $1.2 \mathrm{~g}$ of sterile glass beads $(0.5 \mathrm{~mm})$ for $2 \mathrm{~h}$. This suspension was further diluted (1:10) with sterile distilled water, and FDA was added to a final concentration of $10 \mu \mathrm{g} \mathrm{ml}^{-1}$. The diluted and FDA-stained samples were shaken $(2 \mathrm{~min})$ and centrifuged $(2 \mathrm{~min} ; 10,000 \times g)$. The supernatant was removed and excess FDA was washed off by flushing with $60 \mathrm{mM}$ phosphate buffer. Cells were resuspended in phosphate buffer $(1 \mathrm{ml})$, and $10 \mu \mathrm{l}$ of the supernatant was dried on microscopic slides for $10 \mathrm{~min}$ at $37^{\circ} \mathrm{C}$. Active fluorescent bacterial cells were determined microscopically by counting 10 fields per slide and sample.

DNA was extracted from triplicate field moist soil samples ( $0.7 \mathrm{~g}$ each), using the bead-beating method previously described by Sigler et al. (2002) and pooling triplicate extracts for subsequent PCR amplification. For analysis of RFLP, 16S rRNA gene fragments were amplified using oligonucleotides targeting bacterial sequences using the EUB 338 (5'-ACT CCT ACG GGA GGC AGC-3')/uni-b-rev (5'-GAC GGG CGG TGT GTR CAA-3') primerset (Amann et al. 1995). PCR products were purified with equal volumes of chloroform and reprecipitated with isopropanol. Subsequently, the PCR products $(2 \mu \mathrm{l})$ were digested with HaeIII (2U; Promega, Madison, WI, USA) during overnight incubation at $37^{\circ} \mathrm{C}$. RFLP gels (12\% Bis-/acrylamide) were loaded with $3 \mu$ of the digested PCR products that were separated for $3.5 \mathrm{~h}$ at 200 V. For RFLP analysis, the DCode Universal Mutation Detection System (Bio-Rad, Hercules, CA, USA) was used, the running buffer was $1 \times$ TAE buffer $(0.04 \mathrm{M}$ Tris base, $0.02 \mathrm{M}$ of sodium acetate, and $1.0 \mathrm{mM}$ EDTA, $\mathrm{pH}$ 7.4) at $35^{\circ} \mathrm{C}$. The gel was stained for 30 min with $\mathrm{GelStar}^{\circledR}$ (Cambrex Bioscience, Baltimore, MA, USA), 1:10,000 in $1 \times$ TAE buffer. The restriction patterns were photographed under UV light using the GelDoc 2000 system and Quantity One ${ }^{\circledR}$ software (Bio-Rad). After using a rolling disk algorithm for background correction, band intensities and relative band position were determined. Digital image data were exported to the statistical software SPSS 11.0. Hierarchical cluster analysis was performed using the Ward's method in SPSS.

We obtained PCR products for DGGE using the primers F 968-GC (5'-CGC CCG GGG CGC GCC CCG GGC GGG GCG GGG GCA CGG GGG GAA CGC GAA GAA CCT TAC-3') and R-1401 (5'-CGG TGT GTA CAA GAC CC-3') as described by Nübel et al. (1996). Each PCR reaction contained $1 \times \mathrm{PCR}$ buffer, $2 \mathrm{mM} \mathrm{MgCl}, 0.2 \mathrm{mM}$ of each deoxyribonucleotide triphosphate, $0.5 \mu \mathrm{M}$ of each primer, $0.2 \mathrm{mg} \mathrm{ml}^{-1}$ BSA, $1 \mathrm{U}$ of Taq polymerase (Invitrogen, Carlsbad, CA, USA), and $1 \mathrm{ng}$ of template DNA. PCR products were screened on a $1 \%$ agarose gel. Equal amounts of PCR products were electrophoresed on a $8 \%$ polyacrylamide denaturing gel $(35-60 \%$ denaturant gradient consisting of urea and formamide as defined by Muyzer et al. (1993). Gels were run in $1 \times \mathrm{TAE}$ at $60^{\circ} \mathrm{C}$ for $5 \mathrm{~h}$ at $200 \mathrm{~V}$ using the DCode System, stained, and analyzed as described for RFLP.

Shannon diversity index was calculated from DGGE band intensity data according to

$H=-\sum_{j=1}^{x} p_{i} \ln p_{i}$

with $p_{i}$ being the proportional intensity of band $i$ to total band intensity. Richness is the number of identified phylotypes (identifiable DGGE bands per lane).

We measured five different extracellular enzymatic activities involved in carbon, nitrogen, and phosphorus cycling. All measurements were made in triplicates. Saccharase activity was determined according to the method by Schinner and von Mersi (1990), which was adapted for glacier forefield soils. Briefly, field moist soils $(5 \mathrm{~g})$ were mixed with $5 \mathrm{ml}$ of sucrose solution $(1.2 \%)$ and $5 \mathrm{ml}$ of acetate buffer ( $2 \mathrm{M}$, pH 5.5). After incubation for $3 \mathrm{~h}$ at $50^{\circ} \mathrm{C}$, the released reduced sugars were determined photometrically at $690 \mathrm{~nm}$. $\beta$-Glucosidase activity was quantified according to the method described by Tabatabai (1994). Samples were measured by colorimetric determination of $p$-nitrophenol released by $\beta$-glucosidase after incubation in a $p$-nitrophenyl- $\beta$-D-glucoside solution. We quantified urease activity according to Kandeler and Gerber (1988) by colorimetrical determination of the ammonia released after incubation of field moist soil samples $(5 \mathrm{~g})$ with $2.5 \mathrm{ml}$ urea solution (Kandeler and Gerber 1988). Estimations of alkaline and acid phosphatase activity were performed according to the method described by Tabatabai (1994). For both measurements, field moist soil (1 g) was mixed with $4 \mathrm{ml}$ of alkaline $(\mathrm{pH} 11)$ or acid $(\mathrm{pH} 6.5)$ modified universal buffer accordingly, together with toluene $(0.25 \mathrm{ml})$ and $1 \mathrm{ml}$ of $p$-nitrophenyl phosphate solution 
$(15 \mathrm{mM})$. All samples were incubated for $1 \mathrm{~h}$ at $37^{\circ} \mathrm{C}$ in the dark. The reaction was stopped by adding $\mathrm{CaCl}_{2}$ at a final concentration of $0.05 \mathrm{M}$, and $\mathrm{NaOH}$ at $0.2 \mathrm{M}$. The phosphatase activity, assayed by $p$-nitrophenol release, was measured photometrically.

\section{Statistical analysis}

Statistical analysis was carried out using the SPSS 11.0 software package. Mean values are given \pm 1 standard error of the mean. The significance threshold was set to 0.05 for the $p$ value.

To test for the distance effects on chemical and physical parameters and on microbial abundance, we applied oneway ANOVA on each parameter set $(n=25)$, with distance classes as fixed factors $[0 \mathrm{~cm}(n=3), 20 \mathrm{~cm}(n=11), 40 \mathrm{~cm}$ $(n=11)]$. To test for pairwise differences between distance classes, we applied unpaired sample $t$ tests to analyze the differences of means.

We applied hierarchical clustering to investigate microbial community fingerprints using the Ward's linkage method. Distances were recorded as squared Euclidian distances.

\section{Results}

The measured chemical and physical soil properties showed no significant effect with distance from the plant (Table 1), although all measures of soil carbon were highest in plant center soil. The measurements revealed the acidic character of the soil, with a pH of 5.03 of the plant center soil of $L$. alpina. TOC values were generally low, ranging from $285.89 \mu \mathrm{g} \mathrm{C}(\mathrm{g} \text { dry soil })^{-1}$ at $0 \mathrm{~cm}$ distance to $127.77 \mu \mathrm{g} \mathrm{C}$ $\left(\mathrm{g}\right.$ dry soil) ${ }^{-1}$ at $40 \mathrm{~cm}$ distance from the plants. Extractable organic carbon was dominated by organic acids [240 to $270 \mu \mathrm{g}$ (g dry soil $)^{-1}$ ], with lactate and formate being the most abundant acids in all samples. Total sugar values were more than a magnitude lower [10 to $13 \mu \mathrm{g}$ glucose (g dry soil ${ }^{-1}$ ]. $\mathrm{NH}_{4}{ }^{-}-\mathrm{N}$ values fluctuated between 5.06 and $2.87 \mu \mathrm{g}$ (g dry soil $)^{-1}$. $\mathrm{NO}_{3}^{-}-\mathrm{N}$ values ranged between 18.06 and $18.69 \mu \mathrm{g}$ (g dry soil $)^{-1}$. Soluble phosphate was around $100 \mu \mathrm{g}$ (g dry soil $)^{-1}$ in plant center soil and below detection at further distance from the plant.

In contrast to chemical data, cell count data showed significant trends with distance from the plant (Table 2). Root biomass significantly decreased with distance from the plant (one-way ANOVA, $p<0.01$ ), but 20 and $40 \mathrm{~cm}$ were not significantly different $(t$ test) (Table 2). DAPI counts were highest in the plant center soils $\left[7.88 \times 10^{8}\right.$ cells (g dry soil) ${ }^{-1}$ ] and significantly decreased to about $50 \%$ at $40 \mathrm{~cm}$. Active bacteria counts (as measured by FDA) also decreased significantly with distance (one-way ANOVA, $p=0.01$ ). On average, about $30 \%$ of the total bacterial cells were detected as active, with no significant effect of distance from the plant. Only DAPI $(t$ test, $p<0.01)$ and active bacteria $(t$ test, $p<0.05)$ showed significant differences between 20 and $40 \mathrm{~cm}$ samples.

RFLP analysis revealed complex restriction patterns (Fig. 1). Cluster analysis revealed no clear distance effects; overall, all samples showed a high degree of similarity. Closely related patterns tended to originate from the same plant, but the plant or site effect was likewise marginal (Fig. 1).

Fingerprinting by DGGE confirmed the diverse microbial community structure and lack of spatial effects (data not shown). However, in comparison to RFLP, the information obtained from DGGE profiling is more directly related to the microbial species level because, theoretically, each DGGE band could be related to a distinct bacterial phylotype (Muyzer et al. 1993). We therefore used DGGE banding information to investigate two different diversity parameters: richness (number of different phylotypes) and Shannon index (Table 3), which is a general diversity parameter.

Species richness, as indicated from DGGE band numbers, was highest in samples from the rhizosphere and decreased with distance (Table 3). Shannon diversity values near the plants were slightly higher than those obtained from profiles at $40 \mathrm{~cm}$ distance ( $p=0.06$; unpaired $t$ test). Overall, the decrease was only marginally significant (Pearson correlation -0.352 , significance 0.07 ).

Like cell counts, several enzyme activities were significantly related to distance (Table 2). Saccharase activity decreased significantly from the plant center soil of $L$. alpina $\left[119.46 \mathrm{nmol}\right.$ glucose $\left.(\mathrm{g} \text { dry soil } \bullet \mathrm{h})^{-1}\right],($ ANOVA, $p<0.01)$ to $29.25 \mathrm{nmol}$ glucose $(\mathrm{g} \text { dry soil } \bullet \mathrm{h})^{-1}$ at $40 \mathrm{~cm}$ distance (Table 2). The ratio of saccharase activity divided by the number of FDA stained bacterial cells also decreased with distance (Table 2), but the trend was not significant $(p=0.155) . \beta$-Glucosidase activity was significantly higher in the plant center soil than in the soil sampled at $40 \mathrm{~cm}$ (ANOVA, $p<0.001$ ). The ratio of $\beta$-glucosidase activity divided by the number of active (FDA stained) bacterial cells followed the same trend, which was also statistically significant, $p<0.001$ (Table 2). The sugar-related enzyme activites showed no significant differences between 20 and $40 \mathrm{~cm}(t$ test $)$. Alkaline phosphatase activity was highest in the plant center soil [57.80 nmol phenol $(\mathrm{g} \text { dry soil } \bullet \mathrm{h})^{-1}$ ] and decreased with distance to $34.63 \mathrm{nmol}$ phenol (g dry soil $\bullet h)^{-1}$ (Table 2 ). Acid phosphatase activity was about an order of magnitude higher $\left[480 \mathrm{nmol}\right.$ phenol $(\mathrm{g} \text { dry soil } \bullet \mathrm{h})^{-1}$ in plant center soil] and decreased significantly with distance (ANOVA, $p<0.01$ ). Differences between 20 and $40 \mathrm{~cm}$ were again not significant. Urease activity fluctuated between 90 and $120 \mathrm{nmol} \mathrm{N}(\mathrm{g} \text { dry soil } \cdot \mathrm{h})^{-1}$ with no significant differences between distance classes (Table 2). 
Table 1 Chemical and physical properties across the investigated distance classes of central L. alpina plants in the Dammaglacier forefield

\begin{tabular}{|c|c|c|c|c|c|}
\hline & \multicolumn{3}{|c|}{ Distance from plant } & \multicolumn{2}{|l|}{ ANOVA } \\
\hline & $0 \mathrm{~cm}(n=3)$ & $20 \mathrm{~cm}(n=11)$ & $40 \mathrm{~cm}(n=10)$ & $F_{1,24}$ ratio & $p$ value $^{\mathrm{a}}$ \\
\hline Soil water content $(\%)$ & $8.01 \pm 2.03$ & $8.32 \pm 1.37$ & $9.58 \pm 1.75$ & 0.22 & 0.81 \\
\hline $\mathrm{pH}$ & $5.03 \pm 0.1$ & $4.91 \pm 0.03$ & $4.92 \pm 0.02$ & 1.67 & 0.21 \\
\hline \multicolumn{6}{|l|}{ Carbon parameters } \\
\hline 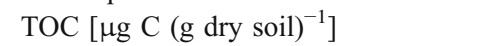 & $285.89 \pm 165.06$ & $221.11 \pm 66.67$ & $127.77 \pm 38.53$ & 0.46 & 0.64 \\
\hline Total sugar $\left[\mu \mathrm{g}(\mathrm{g} \text { dry soil })^{-1}\right]^{\mathrm{b}}$ & $13.08 \pm 3.58$ & $10.94 \pm 1.37$ & $10.42 \pm 1.32$ & 0.32 & 0.73 \\
\hline Total organic acids $\left[\mu \mathrm{g}(\mathrm{g} \text { dry soil })^{-1}\right]^{\mathrm{b}}$ & $344.62 \pm 23.11$ & $283.91 \pm 17.81$ & $313.56 \pm 29.35$ & 0.86 & 0.44 \\
\hline Lactate $\left[\mu \mathrm{g}(\mathrm{g} \text { dry soil })^{-1}\right]^{\mathrm{b}}$ & $268.03 \pm 9.62$ & $240.43 \pm 10.81$ & $248.00 \pm 14.82$ & 0.53 & 0.60 \\
\hline Formate $\left[\mu \mathrm{g}(\mathrm{g} \text { dry soil })^{-1}\right]^{\mathrm{b}}$ & $76.59 \pm 13.62$ & $43.48 \pm 8.10$ & $65.56 \pm 16.16$ & 1.18 & 0.33 \\
\hline \multicolumn{6}{|l|}{ Nitrogen parameters } \\
\hline Total nitrogen $\left[\mu \mathrm{g} \mathrm{N}(\mathrm{g} \text { dry soil })^{-1}\right]$ & $<100^{\mathrm{c}}$ & $<100^{\mathrm{c}}$ & $<100^{\mathrm{c}}$ & - & - \\
\hline 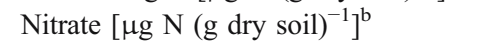 & $18.12 \pm 0.79$ & $18.69 \pm 0.85$ & $18.06 \pm 0.86$ & 0.16 & 0.86 \\
\hline Ammonium [ $\mu \mathrm{g} N\left(\right.$ g dry soil $\left.^{-1}\right]$ & $4.70 \pm 2.66$ & $2.87 \pm 0.53$ & $5.06 \pm 1.84$ & 0.69 & 0.52 \\
\hline Phosphate $\left[\mu \mathrm{g}(\mathrm{g} \text { dry soil })^{-1}\right]^{\mathrm{b}}$ & $108.32 \pm 62.54$ & $<24^{\mathrm{d}}$ & $<24^{\mathrm{d}}$ & - & - \\
\hline
\end{tabular}

Values are given \pm 1 standard error of the mean. The distance effect was tested with ANOVA

${ }^{\text {a }}$ Significance threshold 0.05

${ }^{\mathrm{b}}$ Measurements were done in $0.01 \mathrm{M} \mathrm{CaCl}_{2}$ extracts

${ }^{\mathrm{c}}$ Below detection limit $\left[100 \mu \mathrm{g} \mathrm{N}(\mathrm{g} \text { dry soil })^{-1}\right]$

${ }^{\mathrm{d}}$ Below smallest standard concentration $\left[24 \mu \mathrm{g}(\mathrm{g} \text { dry soil })^{-1}\right]$

\section{Discussion}

L. alpina occurs together with other early pioneering plants such as Agrostis, Cerastium, or Poa species. One of the earliest and most abundant vascular plant species that we investigated at our field site is the perennial plant $L$. alpina. In general we observed single plants or small clusters of plants in the study area, with individual plants reaching up to $10 \mathrm{~cm}$ diameter and making a vigorous appearance, in contrast to the sampling of Edwards et al. (2006), when individual plants were very small, probably representing seedlings from the year. We therefore assume that the plants sampled in this study had established the previous year or earlier.

Table 2 Biological properties across three investigated distance classes of central L. alpina plants

\begin{tabular}{|c|c|c|c|c|c|}
\hline & \multicolumn{3}{|c|}{ Distance from plant } & \multicolumn{2}{|l|}{ ANOVA } \\
\hline & $0 \mathrm{~cm}(n=3)$ & $20 \mathrm{~cm}(n=11)$ & $40 \mathrm{~cm}(n=10)$ & $F_{1,24}$ ratio & $p$ value $^{\mathrm{a}}$ \\
\hline \multicolumn{6}{|l|}{ Biomass } \\
\hline Root biomass [mg (g dry soil) $\left.{ }^{-1}\right]$ & $1.35 \pm 0.95$ & $0.05 \pm 0.03$ & $0.03 \pm 0.01$ & 8.937 & 0.001 \\
\hline DAPI $\left[10^{8}\right.$ cells $\left.(\mathrm{g} \text { dry soil })^{-1}\right]$ & $7.88 \pm 0.58$ & $5.54 \pm 0.45$ & $3.87 \pm 0.34$ & 12.383 & $<0.001$ \\
\hline \multicolumn{6}{|l|}{ Bacterial activity } \\
\hline FDA $\left[10^{8}\right.$ cells $\left.(\mathrm{g} \text { dry soil })^{-1}\right]$ & $2.02 \pm 0.15$ & $1.56 \pm 0.12$ & $1.23 \pm 0.11$ & 5.753 & 0.010 \\
\hline FDA/DAPI $[\%]$ & $25.70 \pm 1.01$ & $29.18 \pm 2.66$ & $33.36 \pm 3.72$ & 0.850 & 0.441 \\
\hline \multicolumn{6}{|l|}{ Enzyme activities } \\
\hline Saccharase activity $\left[\mathrm{nmol}\right.$ glucose $\left.(\mathrm{g} \text { dry soil } \bullet \mathrm{h})^{-1}\right]$ & $119.46 \pm 47.32$ & $40.68 \pm 8.66$ & $29.25 \pm 7.91$ & 7.534 & 0.003 \\
\hline Glucosidase activity $\left[\mathrm{nmol}\right.$ phenol $\left.(\mathrm{g} \text { dry soil } \bullet \mathrm{h})^{-1}\right]$ & $677.53 \pm 231.62$ & $152.60 \pm 27.54$ & $101.60 \pm 17.63$ & 20.375 & $<0.001$ \\
\hline Urease activity $\left[\mathrm{nmol} \mathrm{N}(\mathrm{g} \text { dry soil } \bullet \mathrm{h})^{-1}\right]$ & $101.59 \pm 21.3$ & $127.37 \pm 24.39$ & $99.09 \pm 21.57$ & 0.438 & 0.651 \\
\hline Alkaline phosphatase activity $\left[\mathrm{nmol}\right.$ phenol $\left.(\mathrm{g} \text { dry soil } \bullet \mathrm{h})^{-1}\right]$ & $57.80 \pm 6.94$ & $31.64 \pm 6.01$ & $34.63 \pm 5.86$ & 2.265 & 0.127 \\
\hline Acid phosphatase activity [nmol phenol $\left.(\mathrm{g} \text { dry soil } \bullet \mathrm{h})^{-1}\right]$ & $482.02 \pm 124.75$ & $262.16 \pm 28.82$ & $264.93 \pm 22.20$ & 5.801 & 0.009 \\
\hline \multicolumn{6}{|l|}{ Enzyme activities per FDA stained cells } \\
\hline Saccharase activity $\left[\right.$ fmol glucose $\left.(\text { cell } \bullet \mathrm{h})^{-1}\right]$ & $0.57 \pm 0.19$ & $0.29 \pm 0.08$ & $0.24 \pm 0.07$ & 2.029 & 0.155 \\
\hline Glucosidase activity $\left[\mathrm{fmol}\right.$ phenol $\left.(\text { cell } \bullet \mathrm{h})^{-1}\right]$ & $3.25 \pm 1.04$ & $1.00 \pm 0.17$ & $0.80 \pm 0.11$ & 14.873 & $<0.001$ \\
\hline Urease activity $\left[\mathrm{fmol} \mathrm{N}(\text { cell } \bullet \mathrm{h})^{-1}\right]$ & $0.50 \pm 0.08$ & $0.89 \pm 0.19$ & $0.79 \pm 0.14$ & 0.636 & 0.539 \\
\hline Alkaline phosphatse activity $\left[\mathrm{fmol}\right.$ phenol $\left.(\text { cell } \bullet \mathrm{h})^{-1}\right]$ & $0.28 \pm 0.02$ & $0.20 \pm 0.03$ & $0.30 \pm 0.05$ & 1.626 & 0.219 \\
\hline Acid phosphatse activity $\left[\mathrm{fmol}\right.$ phenol $\left.(\text { cell } \bullet \mathrm{h})^{-1}\right]$ & $2.32 \pm 0.49$ & $1.79 \pm 0.24$ & $2.32 \pm 0.25$ & 1.332 & 0.285 \\
\hline
\end{tabular}

Values are given \pm 1 standard error of the mean. The effect of distance was tested by ANOVA

${ }^{a}$ Significance threshold 0.05 
Fig. 1 RFLP fingerprinting patterns of $16 \mathrm{~S}$ rDNA fragments, originating from different distance classes (top panels) obtained from two transects (a and b) across L. alpina plants together with corresponding results obtained by hierarchical clustering using Ward's method (lower panels)
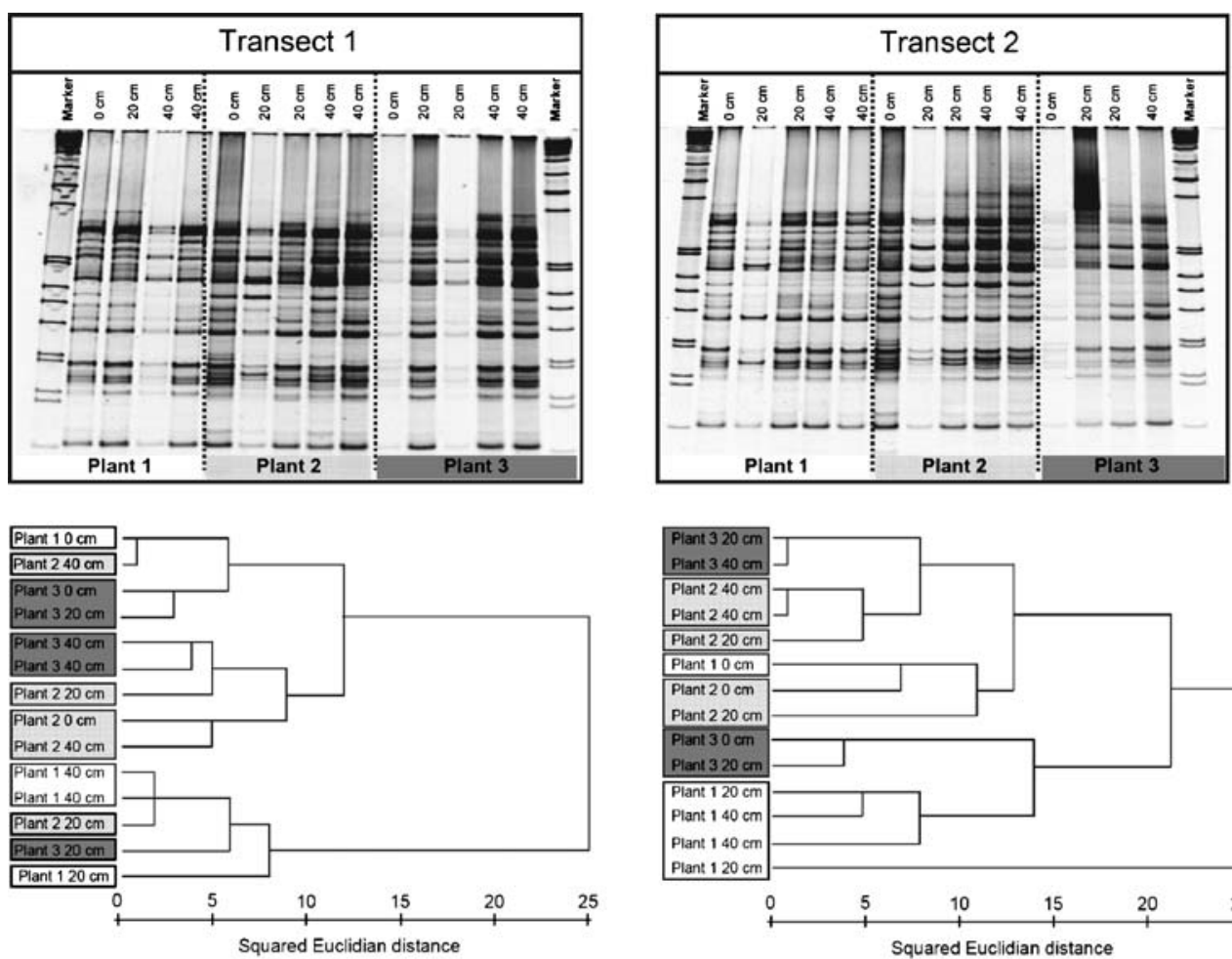

a

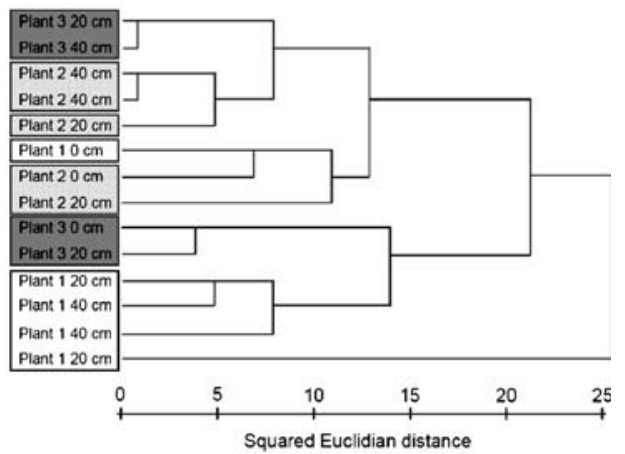

b
We found significantly increased total and active cell numbers and enzymatic activities and elevated soluble organic carbon concentrations in plant center soils, as would be expected based on numerous studies on the rhizosphere effect (e.g., (Youssef and Chino 1987; Badalucco et al. 1996; de Neergaard and Magid 2001; Corgie et al. 2004). The root biomass measurements showed that the root zone of L. alpina did not extend beyond the $10 \mathrm{~cm}$ diameter sampled as plant center soil, indicating that the $40 \mathrm{~cm}$ soil was not in obvious contact with the L. alpina root system. The effect on the microbial biomass, however, clearly extended to the $20-\mathrm{cm}$ samples, with both total and active cell counts significantly increased relative to the $40-\mathrm{cm}$ samples. It is noteworthy that previous studies in similar environments have not observed a significant difference in total cell counts or bacterial biomass between interspace and rhizophere in young soils (Tscherko et al. 2004; Edwards et al. 2006). This may be related to the species and age of the sampled plants, but may also indicate that the sampled interspace/bulk soils could have originated from within the zone of influence of the plant. In the case of Edwards et al. (2006), interspace soil was taken from within $15 \mathrm{~cm}$ of the plant.

Similar to total and active cell counts, several enzymatic activities showed a significant decrease with distance, although differences between the 20 and $40 \mathrm{~cm}$ soil were no longer significant. For saccharase and glucosidase, this result may be related to easily available sugars that can readily be metabolized in the rhizosphere, but it may also reflect the ability of young mineral soil substrates to preserve organic matter and enzymes due to sorption processes on mineral surfaces (Burns and Dick 2002; Guggenberger and Kaiser 2003). Acid phosphatase, which also showed a significant trend with distance, may originate from the plant, as well as microbes (Dick et al. 1983). The

Table 3 Summary of diversity parameters calculated from DGGE banding patterns for samples from three distance classes

\begin{tabular}{lrrrrrr}
\hline & \multicolumn{2}{l}{ Distance from plant } & & PC & sig & \\
\cline { 2 - 5 } & \multicolumn{1}{l}{$0 \mathrm{~cm}$} & $20 \mathrm{~cm}$ & \multicolumn{2}{c}{$40 \mathrm{~cm}$} & & \\
\hline Shannon index & $2.66 \pm 0.07$ & $2.51 \pm 0.08$ & $2.39 \pm 0.11$ & -0.352 & 0.07 \\
Richness & $18.67 \pm 1.20$ & $17.55 \pm 1.55$ & $16.20 \pm 1.69$ & -0.202 & 0.31 & 0.06 \\
\hline
\end{tabular}

Values are given \pm 1 standard error of the mean $(n=27)$

$P C$ Pearson correlation, sig two-tailed significance

${ }^{\mathrm{a}}$ Unpaired sample $t$ test comparing 20 -cm with 40 -cm samples, significance threshold 0.05 
soil we studied has been shown to become both P- and Nlimited in the presence of sufficient carbon (Bleikolm and Bürgmann, unpublished data); however, we observed no effect on urease activity, possibly because urea may not be a significant source of nitrogen in this soil, where soluble nitrogen is mostly inorganic (Edwards et al. 2006). Unlike our results, Tscherko et al. (2004) did not observe enhanced enzymatic activities in the rhizosphere of the alpine grass $P$. alpina in pioneering successional stages, while such differences were occasionally observed in more developed soils. These contrasting results might reflect different underlying environmental parameters such as nutrient availability, organic matter content, and $\mathrm{pH}$ at the research sites, or the different plant species and associated root exudation patterns.

Enzyme assays measure both intracellular and extracellular activities (Nannipieri et al. 2003). In this study, we have applied a new approach that relates enzyme activities to the number of active (FDA-stained) bacteria. This ratio is an alternative to previously used ratios of enzymatic activity to total bacterial biomass measurements, which include dead and dormant cells (Landi et al. 2000). This provides the possibility to qualitatively link the observed enzyme activities to microbial processes. Our results showed that per-cell enzymatic activity generally (and for glucosidase significantly) decreased with distance (Table 2); e.g., the saccharase and glucosidase activities per FDAstained cell in $40 \mathrm{~cm}$ soil were only 42 and $24 \%$ of values of plant center soil, respectively. This would indicate that the bacterial populations show lower levels in the microbial biomass and are increasingly nutrient- or energy-limited with distance from the plant and show lower levels of microbial activity. The overall decrease in activity is therefore due both to the decreasing trend in the biomass and decreasing levels of activity of individual cells.

How can the increased bacterial biomass and activity beyond the actual root zone be explained? It is possible that fine roots, which may not be detected by our root biomass measurements, may provide exudates to the $20 \mathrm{~cm}$ soil. Alternatively, in these young soils, low biomass and a predominantly mineral character (low organic matter and clay content) may allow diffusion or advection of dissolved organic carbon to a much greater extent than has been determined in developed soils (Karthikeyan and Kulakow 2003; Poll et al. 2006). The occurrence of isolated plant patches in young soils could thus promote the formation of strong gradients and lead to a spatially extended impact of plants on young soils. However, the lack of a clear trend in the extractable organic carbon and other chemical parameters rather supports the involvement of fine roots. Finally, the presence of isolated vegetation may have indirect effects that change the living conditions for the microbial biomass independent of the root zone, through effects such as increased aeolic sedimenta- tion rates, decomposition of aboveground biomass, attraction of animals, shading, etc. (Matthews 1992). These effects would have to be studied in more detail in future research.

We performed RFLP and DGGE analysis to characterize the soil microbial community structure at different distances from L. alpina plants. At the observed scale, the differences in microbial activities were not related to an obvious change of the microbial community structure.

Previous research suggests that rhizospheres can have a selective effect on soil bacteria (Marilley et al. 1998). Specific compounds in the root exudates might even selectively stimulate certain beneficial bacterial groups, which have mechanisms to potentially improve plant growth (Griffiths et al. 1999; Dobbelaere et al. 2003; Bürgmann et al. 2005). Edwards et al. (2006) observed different microbial communities in rhizosphere of L. alpina and interspace soil also sampled in this study using DGGE. The different findings may be explained by the different sampling procedures because Edwards et al. (2006) sampled rhizosphere soil directly within the root zone. However, Tscherko et al. (2005) studied the microbial community directly in P. alpina rhizosphere (root-adhering soil) using phospholipid fatty acid analysis and found similar microbial community structure in bulk soil and rhizosphere in young soils. Our results support the conclusion of Tscherko et al. (2005) that in young glacial soils the rhizosphere community is mostly recruited from the bulk soil community. However, they also observed no significant differences in enzymatic activities and microbial biomass, unlike our results. Here we observed that despite a significant increase in numbers and activity of the microbial community in the vicinity of L. alpina, the community was not subject to selective pressure that affected the community composition at the coarse resolution that could be studied using RFLP and DGGE (Nocker et al. 2007). In conclusion, the currently available data remain inconclusive as to under which conditions shifts in microbial community structure in the rhizosphere of pioneer plants occur. This may depend on specific spatial, temporal, or plant speciesrelated effects. The variation of rhizodepostion patterns might be a general mechanism regulating the growth of root-associated bacteria, depending on the environmental conditions and nutrient requirements. Recently, Edwards et al. (2006) reported that the rhizosphere of L. alpina at different successional stages exhibited distinct root-exudation patterns.

In conclusion, we have shown, in accordance to our hypothesis, that vegetational patches occurring in a glacial forefield affected microbial biomass and activity, and that this effect extended to $20 \mathrm{~cm}$ distance from the plant. This creation of relatively large zones of microbial activity may create islands with improved conditions for further biological colonization, e.g., by plants and animals. Similar scenarios have been reported for semiarid and desert zones 
where isolated patches of shrub canopies represent areas of enhanced nutrient availability ("resource islands") (Herman et al. 1995; Su et al. 2004). In contrast to our original hypothesis, the microbial community composition and soil chemistry did not reveal obvious gradients on the studied scale. The dominant members of the bacterial community remained the same despite a doubling of the bacterial cell count, indicating little selective pressure.

\section{References}

Alef K (1995) Estimation of the hydrolysis of fluorescein diacetate. In: Alef K, Nannipieri P (eds) Methods in applied soil microbiology and biochemistry. Academic Press, London, pp 232-233

Amann RI, Ludwig W, Schleifer KH (1995) Phylogenetic Identification and in situ detection of individual microbial-cells without cultivation. Microbiol Rev 59:143-169

Badalucco L, Kuikman PJ, Nannipieri P (1996) Protease and deaminase activities in wheat rhizosphere and their relation to bacterial and protozoan populations. Biol Fertil Soils 23:99-104

Bardgett RD, Walker LR (2004) Impact of coloniser plant species on the development of decomposer microbial communities following deglaciation. Soil Biol Biochem 36:555-559

Bürgmann H, Meier S, Bunge M, Widmer F, Zeyer J (2005) Effects of model root exudates on structure and activity of a soil diazotroph community. Environ Microbiol 7:1711-1724

Burns RG, Dick RP (2002) Enzymes in the environment: activity, ecology, and applications. Marcel Dekker, New York, pp 1-33

Caccianiga M, Andreis C (2004) Pioneer herbaceous vegetation on glacier forelands in the Italian Alps. Phytocoenologia 34:55-89

Chabrerie O, Laval K, Puget P, Desaire S, Alard D (2003) Relationship between plant and soil microbial communities along a successional gradient in a chalk grassland in north-western France. Appl Soil Ecol 24:43-56

Chapin FS, Walker LR, Fastie CL, Sharman LC (1994) Mechanisms of primary succession following deglaciation at Glacier Bay, Alaska. Ecol Monogr 64:149-175

Corgie SC, Beguiristain T, Leyval C (2004) Spatial distribution of bacterial communities and phenanthrene degradation in the rhizosphere of Lolium perenne L. Appl Environ Microbiol 70:3552-3557

Darmody RG, Allen CE, Thorn CE (2005) Soil topochronosequences at Storbreen, Jotunheimen, Norway. Soil Sci Soc Am J 69:1275-1287

de Neergaard A, Magid J (2001) Influence of the rhizosphere on microbial biomass and recently formed organic matter. Eur J Soil Sci 52:377-384

Dick WA, Juma NG, Tabatabai MA (1983) Effects of soils on acid phosphatase and inorganic pyrophosphatase of corn roots (Zea mays). Soil Sci 136:19-25

Dobbelaere S, Vanderleyden J, Okon Y (2003) Plant growthpromoting effects of diazotrophs in the rhizosphere. Crit Rev Plant Sci 22:107-149

Edwards IP, Bürgmann H, Miniaci C, Zeyer J (2006) Variation in microbial community composition and culturability in the rhizosphere of Leucanthemopsis alpina (L.) Heywood and adjacent bare soil along an alpine chronosequence. Microb Ecol 52:679-692

Griffiths BS, Ritz K, Ebblewhite N, Dobson G (1999) Soil microbial community structure: effects of substrate loading rates. Soil Biol Biochem 31:145-153

Guggenberger G, Kaiser K (2003) Dissolved organic matter in soil: challenging the paradigm of sorptive preservation. Geoderma 113:293-310
Haeberli W, Beniston M (1998) Climate change and its impacts on glaciers and permafrost in the Alps. Ambio 27:258-265

Herman RP, Provencio KR, Herreramatos J, Torrez RJ (1995) Resource islands predict the distribution of heterotrophic bacteria in Chihuahuan Desert soils. Appl Environ Microbiol 61:1816-1821

Hodkinson ID, Coulson SJ, Webb NR (2004) Invertebrate community assembly along proglacial chronosequences in the high Arctic. $\mathrm{J}$ Anim Ecol 73:556-568

Kandeler E, Gerber H (1988) Short-term assay of soil urease activity using colorimetric determination of ammonium. Biol Fertil Soils 6:68-72

Karthikeyan R, Kulakow PA (2003) Soil plant microbe interactions in phytoremediation. Adv Biochem Eng Biotechnol 78:51-74

Kaufmann R (2001) Invertebrate succession on an Alpine glacier foreland. Ecology 82:2261-2278

Landi L, Renella G, Moreno JL, Falchini L, Nannipieri P (2000) Influence of cadmium on the metabolic quotient, L-: D-glutamic acid respiration ratio and enzyme activity: microbial biomass ratio under laboratory conditions. Biol Fertil Soils 32:8-16

Marilley L, Vogt G, Blanc M, Aragno M (1998) Bacterial diversity in the bulk soil and rhizosphere fractions of Lolium perenne and Trifolium repens as revealed by PCR restriction analysis of $16 \mathrm{~S}$ rDNA. Plant Soil 198:219-224

Marschner H (1995) Mineral nutrition of higher plants, 2nd edn. Academic Press, London

Matthews JA (1992) The ecology of recently-deglaciated terrain: a geological approach to glacier forelands and primary succession (Cambridge studies in ecology). Cambridge University Press, Cambridge

Mulvaney RL (1996) Nitrogen — inorganic forms. In: Sparks DL et al (eds) Methods of soil analysis, 5th edn. Soil Sci Society of America, Madison, pp 1123-1184

Muyzer G, de Waal EC, Uitterlinden AG (1993) Profiling of complex microbial-populations by denaturing gradient gel electrophoresis analysis of polymerase chain reaction-amplified genes-coding for 16s rRNA. Appl Environ Microbiol 59:695-700

Nannipieri P, Ascher J, Ceccherini MT, Landi L, Pietramellara G, Renella G (2003) Microbial diversity and soil functions. Eur J Soil Sci 54:655-670

Nocker A, Burr M, Camper A, K. (2007) Genotypic microbial community profiling: a critical technical review. Microb Ecol DOI 110.1007/s00248-006-9199-5 (in press)

Nübel U, Engelen B, Felske A, Snaidr J, Wieshuber A, Amann RI, Ludwig W, Backhaus H (1996) Sequence heterogeneities of genes encoding 16S rRNAs in Paenibacillus polymyxa detected by temperature gradient gel electrophoresis. J Bacteriol 178:5636-5643

Ohtonen R, Fritze H, Pennanen T, Jumpponen A, Trappe J (1999) Ecosystem properties and microbial community changes in primary succession on a glacier forefront. Oecologia 119:239-246

Poll C, Ingwersen J, Stemmer M, Gerzabek MH, Kandeler E (2006) Mechanisms of solute transport affect small-scale abundance and function of soil microorganisms in the detritusphere. Eur J Soil Sci 57:583-595

Schinner F, von Mersi W (1990) Xylanase, CM-cellulase and invertase activity in soil: an improved method. Soil Biol Biochem 22:511-515

Sigler WV, Zeyer J (2002) Microbial diversity and activity along the forefields of two receding glaciers. Microb Ecol 43:397-407

Sigler WV, Crivii S, Zeyer J (2002) Bacterial succession in glacial forefield soils characterized by community structure, activity and opportunistic growth dynamics. Microb Ecol 44:306-316

Su Y, Zhao H, Li Y, Cui J (2004) Influencing mechanisms of several shrubs on soil chemical properties in semiarid Horqin Sandy Land, China. Arid Land Res Manag 18:251-263

Tabatabai A (1994) Soil enzymes. In: Weaver RW et al (eds) Methods of soil analysis, 5th edn. Soil Sci Society of America, Madison, pp 775-833 
Tscherko D, Rustemeier J, Richter A, Wanek W, Kandeler E (2003) Functional diversity of the soil microflora in primary succession across two glacier forelands in the Central Alps. Eur J Soil Sci 54 (4):685-696

Tscherko D, Hammesfahr U, Marx MC, Kandeler E (2004) Shifts in rhizosphere microbial communities and enzyme activity of Poa alpina across an alpine chronosequence. Soil Biol Biochem 36:1685-1698

Tscherko D, Hammesfahr U, Zeltner G, Kandeler E, Böcker R (2005) Plant succession and rhizosphere microbial communities in a recently deglaciated alpine terrain. Basic Appl Ecol 6:367-383
Walker TS, Bais HP, Grotewold E, Vivanco JM (2003) Root exudation and rhizosphere biology. Plant Physiol 132:44-51

Youssef RA, Chino M (1987) Studies on the behavior of nutrients in the rhizosphere. 1. Establishment of a new rhizobox system to study nutrient status in the rhizosphere. J Plant Nutr 10:1185-1195

Zarda B, Hahn D, Chatzinotas A, Schönhuber W, Neef A, Amann RI, Zeyer J (1997) Analysis of bacterial community structure in bulk soil by in situ hybridization. Arch Microbiol 168:185-192

Zemp M, Haeberli W, Hoelzle M, Paul F (2006) Alpine glaciers to disappear within decades? Geophys Res Lett 33:L13504 